\title{
FROM THE HISTORY OF DEPORTATION IN UZBEKISTAN
}

\author{
Makhammadyunusov Shavkatbek \\ Researcher of Andizhan State University, Republic of Uzbekistan
}

Article DOI: https://doi.org/10.36713/epra4129

\begin{abstract}
The article is based on archival documents and new scientific literature issues of deported peoples in Uzbekistan in the period of Second World War. Therefore, in this research showed that the statistical data on the numbers of forcibly expelled peoples and ethnic groups are given as well.

KEY WORDS: deportation, Second World War, "punished peoples", ethnic groups, Koreans, Poles, Kalmyk's, Crimean Tatars, Meskhetian Turks, special settlements, rehabilitation.
\end{abstract}

\section{INTRODUCTION}

In the history of the Soviet state, the issue of deportation of various peoples and ethnic groups is of particular relevance, despite several decades of research on this issue. The history of deportation of peoples is also important for Uzbekistan, a Soviet state, where our republic was one of the largest exiles in the Soviet Union from the 1930s to the 1960s.

The deportation or forced deportation of "penalized nations" to Uzbekistan intensified on the eve of World War II and during the war. The war period is the third phase of the history of forced resettlement in the former Soviet Union, during which time the system of special settlements in Uzbekistan expanded and the number of "special transferred" continuously increased.

\section{METHODS}

According to archival documents, 16307 Korean families (74500 people) were relocated to the Far East from October to November 1937 [1, p.373]. The forced deportation of the Koreans was the largest ethnic deportation on the eve of the war, and their resettlement was the basis for the security of the Far East border. After the German fascists invaded the territory of the Soviet Union, total expulsion of separate peoples of the USSR, including those with administrative-territorial autonomy, became popular and legitimized on various grounds. For example, the Decree of the Supreme Soviet of the USSR dated June 22, 1941 entitled the military government to administratively expel all those who were considered "socially dangerous" from the territories declared martial law [2, p.112].

During the war, the "Gulags" exile" significantly decreased. As of October 1, 1941, there were 936,547 "ex-gulags" special displaced persons in the "Gulags exile" [3, p.297]. In the years of war, the decision of the USSR People's Commissars' Council No 1143-280s of October 22, 1938 continued to release the "gulag" children, who were 16 years old, from exile. As a result, by January 1, 1943, the number of exiles in the country had decreased to 724,498, and on January 1, 1944, to 66, 9687. However, this reduction has been compensated by deportation, which is the so-called "punished nations". It was in the 1940s that they formed the main contingent of "special settlements", pushing out "ex-gulags" and other "socially dangerous elements" in exile.

\section{RESULTS AND DISCUSSIONS}

The forced deportation of individual peoples during the war was officially considered as a partysoviet government as a "necessary deportation" and a "preventive security measure". Indeed, the ethnic deportations of 1943-1944 were not "preventative" in nature, but rather as "punishment for crimes against the Soviet state" during the war. Six peoples Karachay, Kalmyk, Chechen, Ingush, Crimean Tatars - were deported under the same label. Ethnic Germans were deported in 1941-1942, North Caucasus peoples in 1943-1944 - Chechens, Ingush, Karachay, Balkans. They were deported by the 


\section{EPRA International Journal of Research and Development (IJRD)}

Presidium of the Supreme Soviet of the USSR on October 12, 1943, by the decisions of the Soviet People's Commissars' Council on October 14, 1943, and by the orders of the State Committee of Defense of the USSR on 31 January 1944. As a result, 608,749 people (36,282 Chechens, 134178 Ingush, 68,327 Karachays, 37,406 Balkars and 6556 other ethnic groups) were deported from the North Caucasus as a result of this event. Some of these (mainly Chechens and Ingush, partly Balkans) were located in the Ferghana Valley regions of Uzbekistan. The Balkans is deported on the basis of the decision of the State Defense Committee No. 5309ss of March 5, 1944 and the Decree of the Presidium of the Supreme Soviet of the USSR dated April 8, 1944 \# 117/6.

In May 1944 the People's Commissar of Internal Affairs of the USSR L.P. Beria instructs the NKVD's territorial bodies to determine whether the Caucasus peoples should be deported to the Kazakh SSR and to the Uzbek SSR. By April 15, 1945, only 2,441 Chechens had been deported from the Georgian SSR. In addition, 4,446 Chechen, Hungarian, Kalmyk, Karachay and Balkhans were deported to Uzbekistan from the Dagestan ASSR, Azerbaijan, Georgia, the USSR, Krasnodar, Rostov and Astrakhan regions [4, p.108].

In total, by the end of $1944,608,749$ people had been deported from the North Caucasus. In particular, the Chechens - 362282, Ingush - 134178, Karachaev - 68,327, Balkaria - 37406 people, 6556 people of other nationalities are registered in exile. On October 1, 1948, 575,768 North Caucasus citizens were listed in the country's special exiles. In MayJune 1944, Crimean Tatars, Bulgarians, Greeks, Armenians and some other ethnic groups were exiled from Crimea. The deportation was based on the following decisions of the State Defense Committee:

Crimean Tatars on decisions of April 2, 1944 No. 5943ss, as of May 11, 1945 \# 5859ss and May 21, 1944 №5937ss; Crimean Bulgarians, Greeks and Armenians by Decision No. 5984ss of June 2, 1944; "Representatives of the Crimean Turkish, Greek and Iranian population" with the expired foreign passport in accordance with the decision No.6100s of June 24, 1944. The main operation of deportation of the Crimean peoples began in the morning of May 18, 1944 and lasted 3 days. There were 228,392 registered Crimean peoples, 224740 of whom were deported on May 11 and June 2, according to the State Defense Committee. Of these, 191014 were Crimean Tatars [5].

Of the deported Crimea, 15,1083 people were placed in the Uzbek SSR $(56,000$ in Tashkent region, 32,000 in Samarkand region, 19,000 in Andizhan, and 16,000 in Ferghana region). The rest were sent to the Ural (Molotov and Sverdlovsk regions, Udmurt ASSR), to the European part of the USSR (Kostroma, Gorky, Moscow and other regions, as well as Mari ASSR). 3652 people (3531 Greeks, 105 Turks, 16 Iranians) were deported to Fergana region of the Uzbek SSR by the decision of the USSR Defense Committee dated 24 June 1944.

The State Defense Committee's decision of June 2, 1944 provided 500 grams of bread, 70 grams of meat and fish, 60 grams of cereals, and 10 grams of fat per day according to the norm \# 1 to provide deportees along the way. We can say that this was more than the norm for prisoners of war and prisoners of war at that time. This has kept the exiles from dying of starvation along the way. For example, 151529 Crimean Tatars of 151,720 Tatars who were deported to the Uzbek SSR in May 1944 were admitted by local NKVD, that is, 191 people $(0.13 \%)$ died along the way. In some cases (mainly in the Kalmyk exile), fatalities were more common. 1640 people $(1.6 \%)$, including 642 children and 736 elderly, were killed in the process of transporting Kalmykia to the area. In addition, 1,010 of those who arrived at the place of exile were hospitalized. It was not the cause of starvation, but the outbreak of infectious diseases among the exiles along the way, and the result of poor medical care. In addition, exiled Crimean Tatars and other Caucasian peoples also experienced various difficulties in exile, with the deaths of Crimea reaching 16,000 in 1944 and nearly 13,000 in 1945 [6, p.5].

According to the decision of the State Committee of the Defense of the Republic of Uzbekistan No. 6279ss of July 31, 1944, the Meskhetian Turks, Kurds, the Hams, Azerbaijanis were exiled from the border areas of the Georgian SSR. Exile took place 3.5 months after the decision was made - in mid-November 1944. Within three days, 25 echelons were sent to exile sites. The total number of settlements reached 94,955, of which about 80,000 were Meskhetian Turks, 8694 were Kurds and 1,385 were nurses. More than half of the exiles from Georgia $(53,133)$ were placed in Uzbekistan (28,598), Kazakhstan (10546) and Kyrgyzstan. They were mainly involved in agricultural activities. By June 6, 1944, 16,175 people (3958 families) were deported from the Crimea, of which 2594 were men, 5406 were women, and 8,175 were children under 16 . They are located in 13 districts. The Union and the government of the country adopted a number of decisions on providing food, housing and employment for medical people, medical care, economic location, and regulation of their legal status. In particular, in connection with the deployment of special Crimean Tatars, on May 16, 1944, the USSR People's Commissariat for Internal Affairs issued an order "On establishing special committees in the NKVD in Uzbekistan". In the city of Fergana and in the region, 33 special committees were established and rights of special displaced persons were regulated. Specially evacuated are 


\section{EPRA International Journal of Research and Development (IJRD)}

employed in the Ferghana region's enterprises, institutions, and collective and state farms in the food, light industry, local industries, power plants, petrochemical industry, construction materials, healthcare, education and cotton sectors.

The government provided loans and monetary loans for economic deportation and housing construction of deported peoples. For example, paragraph 4 of the USSR Defense Committee's Resolution of Crimean Tatars dated May 11, 1944: "The Agricultural Bank (center Kravtsov) provides housing loans and housing loans to 5000 families for the benefit of the displaced persons". Those who emigrated must return them to the state for seven years. According to the information of Bogomolov on June 13, 1945, according to the decision of the State Committee of Defense of the USSR No. 588 dated May 11, 1944, Uzbekistan received 3,312 tons of flour and 1020 tons of deportation from the Crimea. In addition, by the Decision of the Central Executive Committee of the USSR № 6600 of September 25, 1944,6060 tons of grain was specifically allocated to the displaced. This feed was provided to more than 147,000 specially displaced persons, which was not sufficient to provide the displaced. The food supply was suspended by the center in February 1945 [7].

More than 84,000 people resettled from Crimea were unemployed, of whom 13,000 were elderly and 71,000 were children. They are in a very difficult situation regarding food supply. There was a hunger strike among the displaced people, with various diseases following the famine. Therefore, deportation of deportees was urgently needed, as well as food assistance from the collective and state farms. In order to provide the displaced people from the Crimea, the Council of People's Commissars of the UzSSR undertook to distribute $5 \mathrm{~kg}$ of grain and $1 \mathrm{~kg}$ of cereal per month for each person in June-July 1945 for the provision of disabled elderly and children. For this purpose, the ISSR has asked the Center to provide an additional 840 tons of grain and 168 tons of cereals.

The government of the Uzbek Soviet Socialist Republic has taken steps to provide food for the deported, beyond its capacity. On January 30, 1946 the Council of People's Commissars of the UzSSR issued a resolution No. 156-11s "On Grain Assistance for Specially Displaced Persons from the Crimea and the Georgian SSR."The resolution envisages allocation of 1,200 tons of grain at preferential prices from the state fund for sale to the people who are in trouble from the Crimea and Georgia. It was shown that the grain was distributed by the executive committees of the respective provinces in the first and second quarters of 1946 . In the first place, it is planned to allocate $3.5 \mathrm{~kg}$ of food per person to families in difficult situations. Of the allocated 1,200 tons, 390.1 tons are to Tashkent region, 286.0 tons to
Samarkand region, 184.0 tons to Fergana region, 145.0 tons to Andizhan region, 92.4 tons to Namangan region, 51.0 tons to Bukhara Region, 50.4 tons. sent to Kashkadarya region. By April 1, 1946, 526 tons of allotted wheat were distributed to 24,134 families in the respective provinces, or 10,8580 people were provided with food.

In accordance with the decision of the Resettlement Department under the Council of Ministers of the UzSSR from April 24, 1947, No 229 "On allocation of credit for special displaced people from Crimea and Georgia" to the deported farms from the Crimea and Georgia. ruble credit. The distribution of these funds by regions is shown as follows: Andijan region - 2 million 300 thousand rubles; In Altinkul region - 1 million 435 thousand rubles; Izbaskan region - 1 million rubles; In the Lenin region - 1 million rubles; In the Pakhtaabad region 735 thousand rubles; 330 thousand rubles for Stalin region; 200,000 rubles for collective farm named after U.Yusupov in Oyim district [7, p.4].

According to Directive No. 1208 of October 13, 1947, 45 pairs of boots, 20 trousers, and 20 shirts were allocated to special displaced people from the Crimea in Stalin (Shahrikhan), and they should be distributed among families in need of special clothing is said. At the end of the war, efforts have been made to convert exiled Koreans to special status. The Koreans deported in April 1945 were 123,000, of whom 46,000 were living in Kazakhstan, 74500 in Uzbekistan, about 1,000 in Tula and Moscow provinces, and 1,500 in the Komi ASSR. Until now, they were in the "administrative exile" status. The establishment of a special regime for Koreans also required additional resources and certain difficulties. Therefore, the government has not approved any special control over exiled Koreans. On July 4, 1945, by the order of the USSR NKVD \# 1/13219 the status of "specially relocated" to the Koreans, who were temporarily working in the coal field in the Tula region. In 1946, 1,021 Koreans (986 men, 18 women, 17 children) of "specially deported" status were deported and returned to Uzbekistan. As of April 1, 1945 , the geography of specially displaced persons spread to 48 republics, autonomous republics, countries and regions of the USSR, with 192638 special relocations in the Uzbek SSR.

\section{CONCLUSION}

As of July 1, 1950, the number of displaced persons in the Uzbek SSR was 184,122, which were located in cities and villages throughout the country. In other words, the next fate of the people deported to Uzbekistan was among the Uzbek people. Until 1956, the deportees lived under the supervision of the Commanders in the status of "specially relocated". In August 1956 by the decision of the Council of Ministers of the USSR the status of special 
resettlement was abolished and they were included in the list of equal citizens.

\section{REFERENCES}

1. History of the Stalin Gulag. The end of the 1920s the first half of the 1950s. Collection of documents in 7

volumes. /T.5. Special immigrants in the USSR. / Ans. ed. and comp. T.V. Tsarevskaya-Dyakina. M.: "ROSSPEN", 2004. - P. 373-374.

2. Collection of legislative and regulatory acts on repression and rehabilitation of victims of political repression. / Comp. E.A. Zaitsev. - M.: Republic, 1993.-p. 112.

3. Abdullaev M. The system of settlements in Central Asia and the fate of the deported gulags (19301954). - Tashkent: Akademnashr, 2018. - P. 297.

4. Zemskov V.N. Special settlers in the USSR 19301960.-Moscow: Nauka, 2003.-p.108.

5. Dugin A.N. Unknown Gulag: Documents and Facts. - M .: 1999. - S. 273.

6. Collection of legislative and regulatory acts on repression and rehabilitation of victims of political repression. / Comp. E.A. Zaitsev. - M.: Republic, 1993 .-p.194-195.

7. Shahrikhan District State Archive, fund 3, list 1, case 1, page 43 